\title{
Romanowsky Stain
}

National Cancer Institute

\section{Source}

National Cancer Institute. Romanowsky Stain. NCl Thesaurus. Code C158240.

A microscopy staining method that utilizes both cationic and anionic dyes (typically

methylene blue and eosin $\mathrm{Y}$, respectively) for the morphological assessment of cells in a biological specimen. 